\title{
Primipara Undergoing Episiotomy had Lower Postpartum Sexual Function
}

\author{
Primipara yang dilakukan Episiotomi memiliki Fungsi \\ Seksual Pascapersalinan yang Rendah
}

\author{
Irwan, Efendi Lukas, Nusratuddin Abdullah \\ Department of Obstetrics and Gynecology \\ Faculty of Medicine University of Hasanuddin/ \\ Dr. Wahidin Sudiro Husodo Hospital \\ Makassar
}

\begin{abstract}
Objective: To compare postpartum sexual functions between primipara with episiotomy and without episiotomy.

Method: The research was conducted in public service section of Dr. Wahidin Sudiro Husodo hospital and a number of educational hospitals obstetrics and gynecology of Faculty of Medicine of Hasanuddin University, started from February to May 2012. The research evaluated the sexual function of postpartum with episiotomy in 171 primipara, and 150 primipara postpartum without episiotomy. Sexual function was measured by Female Sexual Function Index (FSFI) questionnaire which had been validated in various countries. The research was conducted with cross sectional approach. Samples were withdrawn with consecutive sampling method. The data was processed with SPSS version 17, with chi-square test, and significant level of 0.05 .

Result: Indicated that either the episiotomy or non-episiotomy group has undisturbed sexual function score (>28.5), however, higher score was indicated in non- episiotomy group (65.477) compared to the episiotomy group (59.70), $(\mathrm{p}<0.05)$.

Conclusion: Primipara with episiotomy and breastfeeding has lower sexual functions compared to the non-breastfeeding group, however, it was statistically insignificant $(\mathrm{p}>0.05)$.

[Indones J Obstet Gynecol 2014; 2: 91-95]

Keywords: episiotomy, FSFI, primipara, sexual functions
\end{abstract}

\begin{abstract}
Abstrak
Tujuan: Membandingkan fungsi seksual pascasalin antara primipara yang dilakukan episiotomi dan yang tidak diepisiotomi.

Metode: Penelitian ini dilakukan di BLU RS Dr. Wahidin Sudiro Husodo dan beberapa rumah sakit pendidikan bagian obstetri dan ginekologi Fakultas Kedokteran Universitas Hasanuddin yang dimulai 1 Februari sampai Mei 2012. Penelitian ini menilai fungsi seksual postpartum yang dilakukan episiotomi pada 171 primipara dan 150 primipara postpartum yang tidak dilakukan episiotomi. Fungsi seksual dinilai dengan menggunakan kuesioner FSFI (Female Sexual Function Index) yang telah divalidasi di beberapa Negara. Penelitian ini lakukan secara cross sectional. Pengambilan sampel dilakukan secara consecutive sampling. Data diolah menggunakan SPSS versi 17 dengan uji chi-square test, tingkat signifikansi 0,05.
\end{abstract}

Hasil: Menunjukkan, baik kelompok episiotomi maupun tidak diepisiotomi memiliki skor fungsi seksual yang tidak terganggu $(>28,5)$. Namun skor lebih tinggi pada kelompok yang tidak diepisiotomi (65, $477)$ dibandingkan kelompok yang diepisiotomi $(59,70),(p<0,05)$.

Kesimpulan: Pada primipara yang diepisiotomi dan menyusui memiliki fungsi seksual lebih rendah dibandingkan pada kelompok yang tidak menyusui namun secara statistik tidak bermakna ( $p>0,05)$.

[Maj Obstet Ginekol Indones 2014; 2: 91-95]

Kata kunci: episiotomi, fungsi seksual, FSFI, primipara

Correspondence: Irwan. Aspol Toddopuli Blok A No.49, Makassar. Telephone/mobile: 081389056789. email: irwanbaluku@yahoo.co.id

\section{INTRODUCTION}

Sexuality is an integral component of the life of a normal woman. Comfortable and satisfying sexual intercourse is a factor that plays an important role in the marital relationship for many couples. Sexual dysfunction or Female Sexual Dysfunction (FSD) is defined as a disorder or pain during sex. A survey in the USA found that nearly $30 \%$ of women reported a decrease in their desire for sex. Most find that they no longer enjoy sexual intercourse. Nearly $10-15 \%$ of women experience chronic dyspareunia. Many women who complain of pain or perineal discomfort after childbirth which can survive some time can even cause sexual dysfunction. ${ }^{1,2}$
Sexual dysfunction as a complication of childbirth received less attention in the field of obstetrics, although there have been studies on this subject, but it haven't gained a wide acceptance in obstetric practice. Speculation about the effects of pregnancy and childbirth on postpartum sexual function focused on risk factors such as method of delivery, episiotomy, exclusive breastfeeding, and a history of dyspareunia. Dyspareunia can be divided into primary and secondary. Primary dyspareunia occurs when the pain always comes up during intercourse. Whereas secondary dyspareunia is pain that just arises, with history of painless sex before, such as after childbirth. Barret et al found that $53 \%$ of women during 3 months post- 
partum and $31 \%$ of women at 6 months postpartum were experiencing a loss of sexual desire after the birth of her first child them..$^{2-4}$

Several studies on the relationship between dyspareunia with vaginal delivery accompanied by damage to the perineum (including episiotomy) found that the time to resume and the frequency of sexual intercourse after childbirth differs on each patient, but it is generally stated that there is a decrease in frequency during and after childbirth. Other researchers said that $50 \%$ of women had sexual intercourse 6-12 weeks after delivery, and the time to resume to normal sexual function and sexual satisfaction depends on the degree of the perineal injury. Abdullah et al in Makassar has conducted research to compare the postpartum sexual function between primipara undergoing episiotomy and not, but the time and sample was too limited. In that study, it was found that there was a difference in sexual function between primiparous with episiotomy performed and primipara with no episiotomy, but this was not statistically significant. Thus, the researchers were interested in performing larger study regarding sexual function after childbirth. ${ }^{5,6}$

The sexual dysfunction will be measured using the Female Sexual Function Index (FSFI). FSFI questionnaire form consists of 19 number of questions which has been developed as an instrument that can be used as self-report instrument to assess the multidimensional nature of sexual dysfunction in women. FSFI is formulated in the USA to assess all aspects of sexual dysfunction in women (desire, arousal, orgasmic and sexual pain disorder) and its validity has been demonstrated in many studies on female sexual dysfunction. ${ }^{7-9}$

The views and expectations of people towards labor has changed. Many issues concerning the mother and the baby that was not included in the management plan in obstetrics is now become very important for patients and physicians. This includes postpartum pain, relaxation of the pelvic floor and sexual function. Recently many studies had been done on the longterm sequelae of damage to the pelvic floor and perineum. If people's expectations about the management of labor increases, the issues such as sexual problems in the period after childbirth should be the concern of every obstetrician. In modern obstetric practice, understanding of topics such as postpartum pain, time to resume to sexual intercourse and changes in in- tervention will facilitate optimal obstetric management. ${ }^{4,10,11}$

This study was conducted to find if there was any difference in sexual function between postpartum primipara who had spontaneous delivery with episiotomy and without episiotomy using the Female Sexual Function Index (FSFI).

\section{METHOD}

This research was conducted at several teaching hospitals for Department of Obstetrics and Gynecology, Faculty of Medicine University of Hasanuddin, including BLU RS Dr. Wahidin Sudiro Husodo, from February 2012 to May 2012. This study was a cross-sectional analytic study, aimed to determine the difference in postpartum sexual function between primiparous who had spontaneous delivery with episiotomy and without episiotomy, using FSFI. Subjects were primiparous 6-12 weeks with and without episiotomy in Makassar dr. Wahidin Sudiro Husodo BLU RS and RS networks are willing to follow the study and met the inclusion criteria. Assessed sexual function postpartum in primiparous who delivered vaginally with episiotomy and do not do an episiotomy by filling out the questionnaire. The researcher explains the purpose and objective of the study to the subjects who participated in the study, and participants signed a consent letter has been provided. Interview conducted by researchers maid (female) respondents who accompanied her husband on the family planning clinic and home visits using FSFI questionnaires with closed questions. Questions about sexual activity includes sexual desire (desire), sexual arousal (arousal), vaginal lubrication (lubrication), sexual satisfaction (orgasm), satisfaction with the relationship held (satisfaction), and dyspareunia (pain) were asked at the questionnaire form then performed by scoring FSFI scoring. Data were analyzed using a computerized program. Data analysis includes descriptive analysis is to calculate and determine the amount, while the analytic calculations using statistical test and Chi square test and Fisher's exact significance is determined based on the value of $\mathrm{p}<0.05$.

\section{RESULT}

The sample was 321 subjects who fulfil the inclusion criteria of this study. There were 171 subjects who had episiotomy performed and 150 who 
didn't. The sexual function was examined according to Guttmenn scale with cut off point of 28.5, in which a subject with score $<28.5$ was considered as having a disturbed sexual function. The characteristics of the subjects that was being analyzed including age, education, monthly income, nutritional status, breastfeeding and the length of marriage. The result was presented in Table 1.

Table 1. Characteristic of the Subjects.

\begin{tabular}{|c|c|c|}
\hline Variable & $\mathbf{N}$ & (\%) \\
\hline \multicolumn{3}{|l|}{ Age } \\
\hline$<20$ & 17 & 5.3 \\
\hline $20-35$ & 296 & 92.2 \\
\hline$>35$ & 8 & 2.5 \\
\hline \multicolumn{3}{|l|}{ Education } \\
\hline Low & 126 & 39.3 \\
\hline High & 195 & 60.7 \\
\hline \multicolumn{3}{|l|}{ Income } \\
\hline$<1.100 .000$ & 103 & 32.1 \\
\hline ô 1.100 .000 & 218 & 67.9 \\
\hline \multicolumn{3}{|l|}{ Nutrition Status } \\
\hline Undernourished & 23 & 7.2 \\
\hline Normal & 238 & 74.1 \\
\hline Overweight & 60 & 18.7 \\
\hline \multicolumn{3}{|l|}{ Breastfeeding } \\
\hline No & 95 & 29.6 \\
\hline Yes & 226 & 70.4 \\
\hline \multicolumn{3}{|l|}{ Length of marriage } \\
\hline 1 year & 137 & 42.7 \\
\hline 2 years & 111 & 34.6 \\
\hline 3 years & 62 & 19.3 \\
\hline 4 years & 10 & 3.1 \\
\hline 5 years & 1 & 0.3 \\
\hline
\end{tabular}

Table 2 showed the comparison of sexual function score between the group who had episiotomy and the group who didn't. According to FSFI, the variable of sexual function score including desire, arousal, lubrication, orgasm, satisfaction, and pain. The score then was examined according to Guttmenn scale. The median was 28.5 , showing that both group did not experience disturbance of sex- ual function. But there was a difference in the mean of each group's total score. The group who did not experience episiotomy had higher score (65.477) compared to the group who experienced episiotomy (59.70) and the difference is statistically significant.

Table 2. Analysis of Sexual Function Comparison.

\begin{tabular}{|c|c|c|c|c|c|}
\hline \multirow{3}{*}{$\begin{array}{l}\text { Sexual } \\
\text { Function } \\
\text { score }\end{array}$} & \multicolumn{4}{|c|}{ Episiotomy } & \multirow{3}{*}{$\underset{\text { value }}{\mathbf{p}}$} \\
\hline & \multicolumn{2}{|c|}{ Yes } & \multicolumn{2}{|c|}{ No } & \\
\hline & Mean & SD & Median & SD & \\
\hline Desire & 5.42 & 0.525 & 6.10 & 1.650 & 0.00 \\
\hline Arousal & 11.33 & 2.803 & 12.29 & 3.545 & 0.00 \\
\hline Lubrication & 13.59 & 3.769 & 14.73 & 3.175 & 0.00 \\
\hline Orgasm & 9.75 & 2.866 & 10.88 & 2.764 & 0.00 \\
\hline Satisfaction & 9.74 & 2.465 & 10.87 & 2.579 & 0.00 \\
\hline Pain & 9.88 & 2.856 & 10.69 & 3.283 & 0.00 \\
\hline Sexual function & 59.70 & 13.55 & 65.47 & 14.361 & 0.00 \\
\hline
\end{tabular}

The relation between episiotomy and sexual function was in Table 3. From 171 subjects who experienced episiotomy, 25 subjects had a disturbed sexual function. Meanwhile, from 150 subject who didn't experience episiotomy, 11 subjects had a disturbed sexual function. The difference was statistically significant with $p$ value of 0.039 , meaning that there was a statistically significant difference in the sexual function between the women who experienced episiotomy and the women who didn't.

Table 3. The Relation between Episiotomy and Sexual Function.

\begin{tabular}{lrrrc}
\hline \hline \multirow{2}{*}{ Sexual function } & \multicolumn{3}{c}{ Episiotomy } & p \\
\cline { 2 - 4 } & Yes & No & Total & \\
\hline Not disturbed & 146 & 139 & 285 & 0.039 \\
Disturbed & 25 & 11 & 36 & \\
Total & 171 & 150 & 321 & \\
\hline \hline
\end{tabular}

\section{DISCUSSION}

Most subjects were from the age group of 20-35 years old. Based on the Center for Disease Control and Prevention in 2009, the fertile age of women is from 15 to 44 years old. Age correlates with the level of estrogen secretion that could improve li- 
bido and dyspareunia. The subjects of this study were still in the range of fertile age, when the hormone still functions well. Thus it didn't affect the result of this study. ${ }^{7}$

Based on the education background, most subjects have a high education (60.7\%). Based on the Indonesia National Survey in 2005, the number of non-illiterate in South Sulawesi was $82.20 \%$ with the average education was senior high school.

Most subjects' income was more than 1,100,000 Rupiah (67.9\%). The Regional Minimum Wage stated that monthly income below 1,100,000 rupiah was categorized as below the poverty line. Thus, most subjects were economically above the poverty line.

On average, the nutritional status of the subjects were normal, and there was no difference between the groups. So does the breastfeeding status.

Sexual dysfunction or female sexual dysfunction (FSD) is defined as a disturbance or pain during sex. A survey in the USA found that nearly $30 \%$ of women reported a decrease in their desire for sex. Most find that they no longer enjoy sexual intercourse. Nearly $10-15 \%$ of women experience chronic dyspareunia. Many women who complain of pain or perineal discomfort after childbirth which can longer for some time and can even cause sexual dysfunction. ${ }^{1}$

At first episiotomy is performed for the purpose of preventing too much stretch of the perineum during parturition and it is considered easier to suture a straight wound than ragged tissue rupture. But it turns out a number of studies have shown that routine episiotomy increases the side effects of post-copy, among other perineal pain, dyspareunia, incontinensia Alvi and sexual dysfunction. ${ }^{2}$

In this study, according to FSFI and Guttmenn scale, the median score was 28.5 , showing that both group did not experience disturbance of sexual function. But there was a difference in the mean of each group's total score. the group who did not experience episiotomy had higher score (65.477) compared to the group who experienced episiotomy (59.70) and the difference is statistically significant.

Amelia et al in 2010, found that there was no significant difference in all the sexual function measured $(p=0.261)$ in both groups. Although two previous studies give different results, but con- cluded that the presence of perineal trauma directly related to pain during sexual intercourse where the more severe degree perineal injury, the more severe the degree of pain by itself lead to sexual dysfunction. The episiotomy pain in women varies depending on the method of stitching (versus the two-layer, three-layer), suture techniques (continuous versus interrupted suture), the type of suture used (polyglycolic acid versus chromic catgut), and the ability of the practitioner's own. ${ }^{7}$

In this study, all epiosiotomy was performed with 2.0 cat gut in accordance with the standards of the Hospital facilities and the practitioners who performed an episiotomy had been through the course Normal Delivery Care (APN), so the type of suture and the episiotomy methods in both groups had no difference.

According to Bertnicka $\mathrm{H}$ et al, human sexuality during pregnancy and the postpartum period, could be interfered by breastfeeding. Women who breastfeed usually suffer dyspareunia because an increase in the production of prolactin, which inhibits the action of enzyme aromatase. Thus androgens can not be converted into estrogen, causing a decrease in the production of estrogen, and consequently, the lubrication of the vaginal wall. ${ }^{12}$

This study found a relationship between sexual function and the breastfeeding status in the group that experienced episiotomy. From 128 subjects who breastfeed in the episiotomy group, 22 subjects had a disturbed sexual function (17.2\%). Meanwhile, from 40 subjects who did not breastfeed in the episiotomy group, 3 subjects had a disturbed sexual function. But, the difference is not statistically significant $(\mathrm{p}=0.101)$. The weakness of this study was that we did not acknowledge how often did the subject breastfeed and how much the prolactin increased due to breastfeeding. But we could see that breastfeeding is not a threat to a woman's sexual function, since the number of breastfeeding women who experienced disturbed sexual function is very low (1 in 10). And studies also suggested that the sexual function will be restored to normal once the woman stop breastfeeding.

\section{CONCLUSION}

Primipara with episiotomy and breastfeeding has lower sexual functions compared to the nonbreastfeeding group, however, it was statistically insignificant $(p>0.05)$. However, further research 
on sexual function after episiotomy with different suturing methods and suture is still needed.

\section{REFERENCES}

1. Elder J. Braver Y. Female sexual dysfunction. [cited; Available from: http://www.clevelandclinicmeded.com

2. Signorello L, Harlow B, Chekos A, Repke J. Postpartum sexual functioning and its relationship to perineal trauma: A retrospective cohort study of primiparous women. Am J Obstet Gynecol. 2001; 184(5): 881-90.

3. Kettle C, Ismail $\mathrm{K}, \mathrm{O}$ 'Mahony $\mathrm{F}$. Dyspareunia following childbirth. Obstet Gynecol. 2005; 7: 245-9.

4. Connolly A, Thorp J, Pahel L. Effects of pregnancy and childbirth on postpartum sexual function: a longitudinal prospective study. Int Urogynecol J. 2005; 16: 263-7.

5. Glazener. Sexual function after childbirth: women's experiences, persistent morbidity and lack of professional recognition. Bri J Obstet Gynaecol. 1997; 104(3): 330-5.

6. Safarinejad MR, Kolahi AA, Hosseini L. The effect of the mode of delivery on the quality of life, sexual function, and sexual satisfaction in primiparous women and their husband. J Sex Med. 2009; 6: 1645-67.
7. Viswanathan M, Hartmann K, Palmieri R, et al. The use of episiotomy in obstetric care. [cited; Available from: http://www.ahrq.gov/clinic/tp/epistp.htm

8. Meston C. Validation of the Female Sexual Function Index (FSFI) in Women with Female Orgasmic Disorder and in Women with Hypoactive Sexual Desire Disorder. J Sex Marital Therapy. 2003; 29: 39-46

9. Rosen R, Brown C, Heiman J, et al. The Female Sexual Function Index (FSFI): A Multidimensional Self-Report Instrument for the Assessment of Female Sexual Function. J Sex Marital Therapy. 2000; 26: 191-208.

10. Baram D, Basson R. Sexuality, Sexual Dysfunction, and Sexual Assault. In: Berek JS, editor. Berek and Novak's Gynecology. $14^{\text {th }}$ ed: Lippincott Williams and Wilkins; 2007: 313-46.

11. Woranitat ST. Sexual Function during the Postpartum Period. J Med Assoc Thai 2007; 90(9): 1744-8.

12. Klein MC, Robbins JM, Kaczorowski J, et al. Relationship of episiotomy to perineal trauma and morbidity, sexual dysfunction, and pelvic floor relaxation. Am J Obstet Gynecol. 1994; 171(3): 591-8. 